\title{
BACTERIAL ENTOMOPATHOGENS IMPROVE CEREAL ESTABLISHMENT IN THE PRESENCE OF GRASS GRUB LARVAE
}

\author{
S.D. YOUNG, R.J. TOWNSEND and M. O'CALLAGHAN \\ AgResearch, Lincoln Research Centre, Private Bag 4749, Christchurch 8140, \\ New Zealand
}

Corresponding author: sandra.young@agresearch.co.nz

\begin{abstract}
Grass grub (Costelytra zealandica) larvae can damage or kill establishing cereal seedlings. Two entomopathogenic bacteria, applied as seed coatings, were investigated as a means of protecting emerging wheat seedlings. Seeds coated with Serratia entomophila or Yersinia sp. nov. were planted outdoors in pots containing grass grub larvae at rates equivalent to 70 and 140 larvae $/ \mathrm{m}^{2}$. Seedling establishment was significantly increased in both bacterial treatments compared to untreated controls, with S. entomophila-coated seed having the higher establishment rate, $94 \%$ at both larval densities, although this was not significantly different from the Yersinia sp. nov. treatment at the highest larval density. When included in a comparison of chemical seed dressing treatments for grass grub, a $S$. entomophila-coated seed treatment was as efficacious as standard insecticide treatments, indicating there is good potential to develop this bacterium as an alternative to chemical pesticides for use in cereal crops. Keywords: grass grub, Costelytra zealandica, wheat, microbial control, Serratia entomophila, Yersinia sp.
\end{abstract}

\section{INTRODUCTION}

The New Zealand grass grub, Costelytra zealandica (White) (Coleoptera: Scarabaeidae), is a serious pasture pest. The larvae can also have a detrimental effect on the establishment of autumn sown cereals by feeding on the roots of emerging seedlings. Third instar larvae actively feed in the top $2 \mathrm{~cm}$ of soil during late summer to mid winter when autumn cereal crops are germinating (Chapman 1984). Cereal crops that follow pastures with high grass grub populations are particularly at risk (Burnett 1984).

Bacterial biological control agents for grass grub in pasture have previously been investigated. Serratia entomophila, sold as a granulated formulation (bioshield ${ }^{\mathrm{TM}}$, Ballance Agri-Nutrients, Tauranga, New Zealand) for direct drilling into pasture, is a naturally occurring soil bacterium that causes amber disease specific to grass grub. Infected grubs cease feeding within 3 days and begin to die within 4 weeks (Jackson et al. 1993).

Seed coating has previously been considered as a method of delivering S. entomophila into the feeding zone of grubs on carrot seed (Wright et al. 2005) and ryegrass (Sadler et al. 1992). In this study, the efficacy of $S$. entomophila, when applied as a wheat seed coating for protection from grass grub, was investigated in an outdoor pot trial together with standard chemical insecticides commonly used for grass grub control in cereals. In a second trial, investigating biological control agents as seed coatings, S. entomophila was compared with Yersinia sp. nov., a newly discovered, endemic bacterial species that has broad insecticidal activity, including against grass grub (Hurst \& Glare 2006). 


\section{MATERIALS AND METHODS \\ Bacterial cultures and seed coating}

Starter cultures were prepared from agar plates of S. entomophila (strain AgR626) and Yersinia sp. nov. (strain MH96). Cultures were incubated overnight in $10 \mathrm{ml}$ Luria Bertani (LB) broth (Miller 1972) at $30^{\circ} \mathrm{C}$ and $250 \mathrm{rpm}$. Flask cultures $(500 \mathrm{ml}$ ) of raw sugar yeast extract medium (40 g raw sugar, $10 \mathrm{~g}$ yeast extract, $2 \mathrm{~g}$ urea, $0.86 \mathrm{~g} \mathrm{Na}_{2} \mathrm{HPO}_{4}$, $0.46 \mathrm{~g} \mathrm{KCl}$ and $0.68 \mathrm{~g} \mathrm{NH}_{4} \mathrm{NO}_{3}$ in 1 litre distilled water) for $S$. entomophila and LB broth for Yersinia sp. nov. were each inoculated with $5 \mathrm{ml}$ of starter culture, and incubated for $72 \mathrm{~h}$ at $30^{\circ} \mathrm{C}$ and $200 \mathrm{rpm}$. Bacterial cells were concentrated by centrifugation at $8000 \mathrm{rpm}$ for $25 \mathrm{~min}$ at $16^{\circ} \mathrm{C}$ and resuspended in $0.1 \mathrm{M}$ phosphate buffer equal to $10 \%$ of the original volume. The bacteria were applied to the seed by biopolymer coating (Johnson \& Pearson 2001).

Bacteria present on seed were enumerated by mixing $1 \mathrm{~g}$ of seed with $10 \mathrm{ml}$ of $0.1 \mathrm{M}$ phosphate buffer and shaking at maximum speed for $10 \mathrm{~min}$ on a wrist action shaker. The mixture was then dilution plated onto LB agar and the plates incubated at $30^{\circ} \mathrm{C}$ for $24 \mathrm{~h}$ before enumeration of colonies. The initial bacterial loading on seed in the insecticide comparison trial was $5.3 \times 10^{9}$ colony forming units (cfu)/g seed and in the second trial $3.8 \times 10^{9} \mathrm{cfu} / \mathrm{g}$ seed for $S$. entomophila and $1.9 \times 10^{9} \mathrm{cfu} / \mathrm{g}$ for Yersinia sp. nov. These rates are equivalent to $10 \times$ the bacterial application rate achieved when applying the commercial $S$. entomophila product bioshield ${ }^{\mathrm{TM}}$.

\section{Pot trial setup}

Outdoor pot trials were set up at the AgResearch Lincoln farm in April 2002 (Trial 1) and May 2008 (Trial 2). Plastic pots ( $30 \mathrm{~cm}$ diameter) with mesh bases were set in bedding sand and filled with Wakanui silt loam to a depth of $25 \mathrm{~cm}$. Wheat seeds were sown to a depth of 3-4 cm in two lines of ten across each pot, with six replicate pots per treatment in a randomised block design. The seeding rate and distance between rows approximated normal cereal sowing practice. The wheat cultivars used were both autumn sown varieties; 'Centaur' was used in the insecticide comparison trial (Trial 1) and 'Alberic' was used for Trial 2. For the insecticide trial the following treatments were applied at recommended field rates: $3 \mathrm{~kg} /$ ha terbufos; $5.5 \mathrm{~kg} /$ ha diazinon; $0.90 \mathrm{ml}$ imidacloprid/ $\mathrm{kg}$ seed dressing; $3 \mathrm{~kg} / \mathrm{ha}$ diazinion plus $0.90 \mathrm{ml}$ imidacloprid $/ \mathrm{kg}$ seed dressing; and $S$. entomophila-coated seed. Bare seed was included as a control treatment.

In Trial 2 treatments were: S. entomophila-coated seed; Yersinia sp. nov. coated seed; coated seed with no added bacteria as a control; and bare seed.

Field-collected, third instar grass grub larvae were pre-fed carrot cubes in trays over 3 days to select healthy, feeding individuals. Larvae were placed on the soil surface $24 \mathrm{~h}$ after sowing and allowed to bury themselves in the soil. Any grubs remaining on the surface after 20 min were removed and replaced with healthy specimens to avoid using any larvae damaged by handling. The grubs were applied at rates of 5 or 10 grubs per pot to approximate field rates of 70 larvae $/ \mathrm{m}^{2}$ (moderate damage causing population) and 140 larvae $/ \mathrm{m}^{2}$ (high population).

Trial 1 was watered 6 days post sowing to approximate $15 \mathrm{~mm}$ rainfall as per label recommendations of granular insecticides. Both trials were visually assessed at weekly intervals to ensure soil moisture did not fall below $15 \%$, which is recommended for survival of S. entomophila, and watered as necessary.

\section{Trial sampling}

The insecticide trial was destructively harvested at 54 days post sowing. Numbers of seedlings per pot were counted and all surviving grass grub larvae were collected.

Surviving larvae from the $S$. entomophila and control treatments were assessed in a feeding bioassay to determine if they were diseased, as infected larvae cease feeding. The grubs were placed in individual cells in trays with carrot cubes and visually inspected for symptoms of disease and feeding after 3 days at $15^{\circ} \mathrm{C}$.

Trial 2 was harvested at 60 days post sowing and, in addition to recording the number of seedlings and disease status of surviving grass grubs, the plants were washed clean of soil and oven dried at $80^{\circ} \mathrm{C}$ to determine dry matter weights. The top $20 \mathrm{~cm}$ of soil from 
each pot in the S. entomophila, coated control and bare seed treatments was removed and well mixed, before a $20 \mathrm{~g}$ sub-sample was collected from each to allow enumeration of S. entomophila $\mathrm{cfu} / \mathrm{g}$, by dilution plating soil onto a selective medium (O'Callaghan \& Jackson 1993). As a selective medium for isolation of Yersinia sp. nov. was not available, these bacteria were not enumerated.

Statistical analysis

Data from each trial were analysed separately using analysis of variance and least significant difference test (LSD) at $\mathrm{P}=0.05$, appropriate for a randomised complete block design.

\section{Seedling establishment}

\section{RESULTS}

In Trial 1, all treatments significantly increased wheat seedling establishment in comparison with untreated control seed (Table 1). No significant differences in seedling establishment were found between the chemical insecticide treatments and S. entomophila-coated seed at the same larval densities.

TABLE 1: Percentage wheat seedling establishment at 54 days post sowing in Trial 1.

\begin{tabular}{lclcc}
\hline \multirow{2}{*}{ Treatment } & Trade & \multirow{2}{*}{ Rate } & \multicolumn{2}{c}{ larvae $/ \mathrm{m}^{2}$} \\
\cline { 4 - 5 } & Name & & 90 & 140 \\
\hline S. entomophila & & $5.3 \times 10^{9} \mathrm{cfu} / \mathrm{g}$ seed & 91.4 & 78.6 \\
imidacloprid & Gaucho® & $0.9 \mathrm{ml} / \mathrm{kg} \mathrm{seed}$ & 87.1 & 84.3 \\
terbufos & Counter ${ }^{\circledR}$ & $3 \mathrm{~kg} / \mathrm{ha}$ & 88.6 & 84.3 \\
diazinon & Gesapon ${ }^{\circledR}$ & $5.5 \mathrm{~kg} / \mathrm{ha}$ & 81.4 & 77.1 \\
diazinon+imidacloprid & & $3 \mathrm{~kg} / \mathrm{ha}+0.9 \mathrm{ml} / \mathrm{kg}$ seed & 91.4 & 88.6 \\
Control & & & 48.6 & 1.4 \\
LSD $(\mathrm{P}=0.05)$ & & & 12.7 & 12.7 \\
\hline
\end{tabular}

In Trial 2, S. entomophila-coated seed resulted in better seedling establishment at both larval densities compared with Yersinia sp. nov. coated seed, control coated seed or bare seed (Table 2). However, at the high larval density the difference in seedling establishment between $S$. entomophila and Yersinia sp. nov. coated seed was not significant.

TABLE 2: Percentage wheat seedling establishment at 60 days post sowing in Trial 2.

\begin{tabular}{lccc}
\hline & \multicolumn{3}{c}{ larvae $/ \mathrm{m}^{2}$} \\
\cline { 2 - 4 } Treatment & 0 & 70 & 140 \\
\hline Bare seed & 97.0 & 69.2 & 39.1 \\
Coated control & 90.0 & 76.5 & 26.7 \\
S. entomophila & 97.5 & 94.2 & 94.2 \\
Yersinia sp. nov. & 97.5 & 82.5 & 86.7 \\
LSD $(\mathrm{P}=0.05)$ & 10 & 10 & 10 \\
\hline
\end{tabular}

\section{Survival and disease status of larvae}

In Trial 1, the highest grass grub mortalities occurred in the diazinon treatment at the 70 larvae $/ \mathrm{m}^{2}$ rate, and in the terbufos treatment at the 140 larvae $/ \mathrm{m}^{2}$ rate. Although more live grubs were recovered from the $S$. entomophila treatments, many of these were diseased and not feeding. The number of healthy larvae recovered from this treatment 
was not significantly different to the diazinon or terbufos treatments (Table 3 ). There was no significant advantage gained over the diazinon treatment by combining diazinon with imidacloprid.

TABLE 3: Healthy grass grubs recovered from treatments in Trial 1, expressed as a percentage of the total number introduced.

\begin{tabular}{lcc}
\hline & \multicolumn{2}{c}{ larvae $/ \mathrm{m}^{2}$} \\
\cline { 2 - 3 } Treatment & 70 & 140 \\
\hline S. entomophila & 16.7 & 21.6 \\
imidacloprid & 36.7 & 30.0 \\
terbufos & 16.7 & 8.3 \\
diazinon & 0 & 11.7 \\
diazinon+imidacloprid & 16.7 & 13.3 \\
Control & 86.7 & 91.7 \\
LSD $(\mathrm{P}=0.05)$ & 17.5 & 17.5 \\
\hline
\end{tabular}

In Trial 2, significantly fewer healthy larvae were recovered from pots when seed was treated with Yersinia sp. nov. than in pots where seeds were treated with S. entomophila at both larval densities (Table 4). There were significantly fewer healthy grubs in the bacteria seed treatments than the bare or control seed treatments.

TABLE 4: Healthy grass grubs recovered from treatments in Trial 2, expressed as a percentage of the total number introduced.

\begin{tabular}{lcc}
\hline & \multicolumn{2}{c}{ larvae $/ \mathrm{m}^{2}$} \\
\cline { 2 - 3 } Treatment & 70 & 140 \\
\hline Bare seed & 93.3 & 86.7 \\
Coated control & 86.7 & 91.7 \\
S. entomophila & 70.0 & 45.0 \\
Yersinia sp. nov. & 33.3 & 26.7 \\
LSD $(\mathrm{P}=0.05)$ & 16.7 & 16.7 \\
\hline
\end{tabular}

\section{Plant dry weights}

Total plant dry matter from S. entomophila-coated seed was significantly higher than from the coated control (no bacteria) and bare seed (Table 5). At the density of 70 larvae $/ \mathrm{m}^{2}$, total dry matter was significantly higher from the S. entomophila-coated seed, than from the Yersinia sp. nov. coated seed, but there was no significant difference between the bacterial treatments at the higher rate of 140 grubs $/ \mathrm{m}^{2}$.

TABLE 5: Mean plant dry matter weights (g/pot) in Trial 2, measured post harvest at 60 days after sowing.

\begin{tabular}{lccc}
\hline & \multicolumn{3}{c}{ larvae $/ \mathrm{m}^{2}$} \\
\cline { 2 - 4 } Treatment & 0 & 70 & 140 \\
\hline Bare seed & 1.44 & 0.96 & 0.37 \\
Coated control & 1.30 & 1.01 & 0.33 \\
S. entomophila & 1.47 & 1.50 & 1.41 \\
Yersinia sp. nov. & 1.58 & 1.16 & 1.25 \\
LSD $(\mathrm{P}=0.05)$ & 0.23 & 0.23 & 0.23 \\
\hline
\end{tabular}




\section{Survival of Serratia entomophila in soil}

Serratia entomophila was recovered from soil in pots planted with S. entomophilacoated seed. Over all treated plots the mean was $3179 \mathrm{cfu} / \mathrm{g}$ soil (SEM $=809 \mathrm{cfu} / \mathrm{g}$ soil). There was no significant difference in S. entomophila recovered from soil at different grass grub densities.

\section{DISCUSSION}

Application of insecticidal micro-organisms to seed is an ideal delivery system as it introduces the control agent into the plant rhizosphere where the target pest (in this case grass grub larvae) will be feeding, ensuring rapid contact between the pathogen and its host. In some cases, feeding insects are attracted to plant roots, so likelihood of the larvae becoming infected is increased. A critical success factor in this approach is the introduction of sufficient microbes to the root zone such that the insect becomes infected before causing damage to the germinating seed or emerging seedling.

The application of Serratia entomophila to wheat seeds significantly improved seedling establishment in the presence of grass grub larvae at both moderate and high feeding pressure. The rate of seedling establishment of seeds treated with S. entomophila was consistent with that achieved using standard insecticide treatments. All treatments provided similar levels of protection for establishing wheat seedlings. In a second trial carried out to validate the efficacy of $S$. entomophila, a comparable control rate was again achieved. Despite lower initial bacteria loading on seed compared with S. entomophila, the novel bacterial strain Yersinia sp. nov. also gave good grass grub control, with plant yields and seedling establishment not significantly different to $S$. entomophila at a high larval density. To date, work on fermentation and formulation of this bacterium has been limited; further optimisation of growth media and conditions may allow increased bacterial loading and improve seed coating efficacy with this species.

These trials have demonstrated that the potential exists for the use of microbial control agents as an alternative to chemical pesticides in protection of wheat seedlings against grass grub larval feeding damage. Practical considerations in the implementation of this research include the ability to treat seed with microbial inoculum that remains viable during seed storage. Previous studies on microbial inoculation of seed (e.g. O'Callaghan et al. 2006; Wright et al. 2005) suggest that it should be possible to supply seed with a reasonable shelf-life to growers, in particular because much is now known about the stabilisation of S. entomophila (Johnson et al. 2001). There is also potential to develop seed coatings containing additional beneficial micro-organisms, such as bacterial antagonists for protection of seedlings from soil-borne plant pathogens and growthpromoting fungi such as Trichoderma species.

\section{ACKNOWLEDGEMENTS}

We thank Von Johnson and Jayanthi Swaminathan for bacterial seed coating, David Saville for undertaking statistical analysis, and Hannes Witte for his assistance with field and laboratory work. Work carried out in Trial 1 was funded by the Foundation for Arable Research and Trial 2 was funded by the New Zealand Foundation for Research, Science and Technology Contract C10X0706.

\section{REFERENCES}

Burnett PA 1984. Cereal crop pests. In: Scott RR ed. New Zealand pest and beneficial insects. Lincoln University College of Agriculture, Canterbury, New Zealand. Pp. 153-167.

Chapman RB 1984. Pasture pests. In: Scott RR ed. New Zealand pest and beneficial insects. Lincoln University College of Agriculture, Canterbury, New Zealand. Pp. 129-142.

Hurst MRH, Glare TR 2006. Novel bacteria and uses thereof. Patent no. PCT/ NZ2007/000146. Australia. 
Jackson TA, Huger AM, Glare TR 1993. Pathology of amber disease in the New Zealand grass grub Costelytra zealandica (Coleoptera: Scarabaeidae). Journal of Invertebrate Pathology 61: 123-130.

Johnson VW, Pearson JF 2001. A thermo-stable bio-matrix and method of preparation. Patent no. 506484. New Zealand.

Johnson VW, Pearson JF, Jackson TA 2001. Formulation of Serratia entomophila for biological control of grass grub. New Zealand Plant Protection 54: 125-127.

Miller JH 1972. Experiments in molecular genetics. Cold Spring Harbor Laboratory, Cold Spring Harbor, New York, USA. 466 p.

O'Callaghan M, Jackson TA 1993. Isolation and enumeration of Serratia entomophila - a bacterial pathogen of the New Zealand grass grub, Costelytra zealandica. Journal of Applied Bacteriology 75: 307-314.

O'Callaghan M, Swaminathan J, Lottmann J, Wright DA, Jackson TA 2006. Seed coating with biocontrol strain Pseudomonas fluorescens F113. New Zealand Plant Protection 59: 80-85.

Sadler TJ, Jackson TA, Moorhouse AM 1992. Use of bacterial seed coatings for protection of grass seedlings from grass grub attack. Proceedings of the XIX International Congress of Entomology, Beijing, China. p. 336.

Wright DA, Swaminathan J, Blaser M, Jackson TA 2005. Carrot seed coating with bacteria for seedling protection from grass grub damage. New Zealand Plant Protection 58: 229-233. 